\title{
Landfills - territorial issues of cities from North-East Region, Romania
}

\author{
Florin - Constantin MIHAI ${ }^{1, *}$, Pavel ICHIM ${ }^{1}$ \\ ${ }^{1}$ Faculty of Geography and Geology, Department of Geography, University of "Alexandru loan Cuza”, B-dul Carol I, Nr. \\ 20 A, RO-700505, lasi, Romania \\ * Corresponding author, mihai.florin86@yahoo.com
}

Received on <07-05-2013>, reviewed on <21-09-2013>, accepted on <26-10-2013>

\begin{abstract}
Landfilling prevails in waste management options in Romania like others new EU members, being contrary to the concept of waste hierarchy promoted in recent years by EC. Waste disposal is done usually in non-compliant landfills and Government established a program to close these sites. This paper aims to analyse the transition from traditional waste management systems to an integrated system at national, regional and local scale. Assessment of landfills location based on buffer analysis (using GIS techniques) is made according to the proximity of five critical factors (CF) such as: residential area, industry \& commercia units, agricultural lands, rivers \& lakes, forest and protected areas, all these factors being sensitive to pollution. Thus, most of these old sites are badly or improperly located related to surroundings and only few have an acceptable location in the study area! Therefore, the proposed method can be a necessary tool in EIA studies of these environmental threats at regional scale.
\end{abstract}

Keywords: landfill, urban area, GIS, multi-scale analysis, waste management

\begin{abstract}
Rezumat. Depozite de deșeuri - probleme teritoriale ale orașelor din Regiunea Nord-Est, Romania

Depozitarea predomină în optiunile de management al deșeurilor în România asemeni altor state noi membre, fiind contrar conceptului de ierarhie a deșeurilor promovat în ultimi anii de CE. Eliminarea deșeurilor se realizează de obicei în depozite neconforme, iar Guvernul a stabilit un calendar de închidere a acestor amplasamente. Această lucrare iși propune să analizeze tranziția de la un sistem tradițional de management al deșeurilor către un sistem integrat la nivel național, regional și local. Evaluarea amplasamentelor acestor depozite bazată pe analiza buferelor (utilizând tehnici SIG) este realizată in funcție de proximitatea a cinci factori critici, cum ar fi: zona rezidetială, unitățile industriale și comerciale, terenuri agricole, râuri și lacuri, păduri și arii protejate, toți acești factori fiind sensibili la poluare. Astfel, majoritatea acestor amplasamente sunt rele sau necorespunzatoare față de imprejurimi și numai câteva au o amplasare acceptabilă in zona de studiu! Prin urmare, metoda propusă poate deveni un instrument necesar în studiile EIM ale acestor amenințări de mediu la scară regională.
\end{abstract}

Cuvinte-cheie: depozite de deșeuri, zone urbane, SIG, analiză multi-scalară, managementul deșeurilor

2008;). In the case of the existing ones, the buffer analysis of non-compliant landfills from Neamt County (North-East Region) reveals certain environmental issues on local landscape (Mihai et al., 2013a; Mihai et al., 2013b). Regional studies on waste management issue are necessary for a multiscale assessment of EU targets and objectives related to geographical features at regional and local scale (D'Alisa et al., 2012, Passarini et al., 2011; Lin and Chen, 2009; Mazzanti et al., 2009). Also, spatial analysis of waste indicators are a necessary tool in assessment or monitoring of waste management sector (Keser et al., 2012; Pandey et al., 2012; Mihai, 2012b, Mihai and Lămășanu, 2013).

\section{Methods}

In order to examine the current situation of noncompliant landfills at urban level and location of new waste management facilities, we consulted several reports of environmental authorities, regional and local waste management plans. Spatial analysis of indicators using thematic cartography reflects regional and local disparities (Fig. 1). 


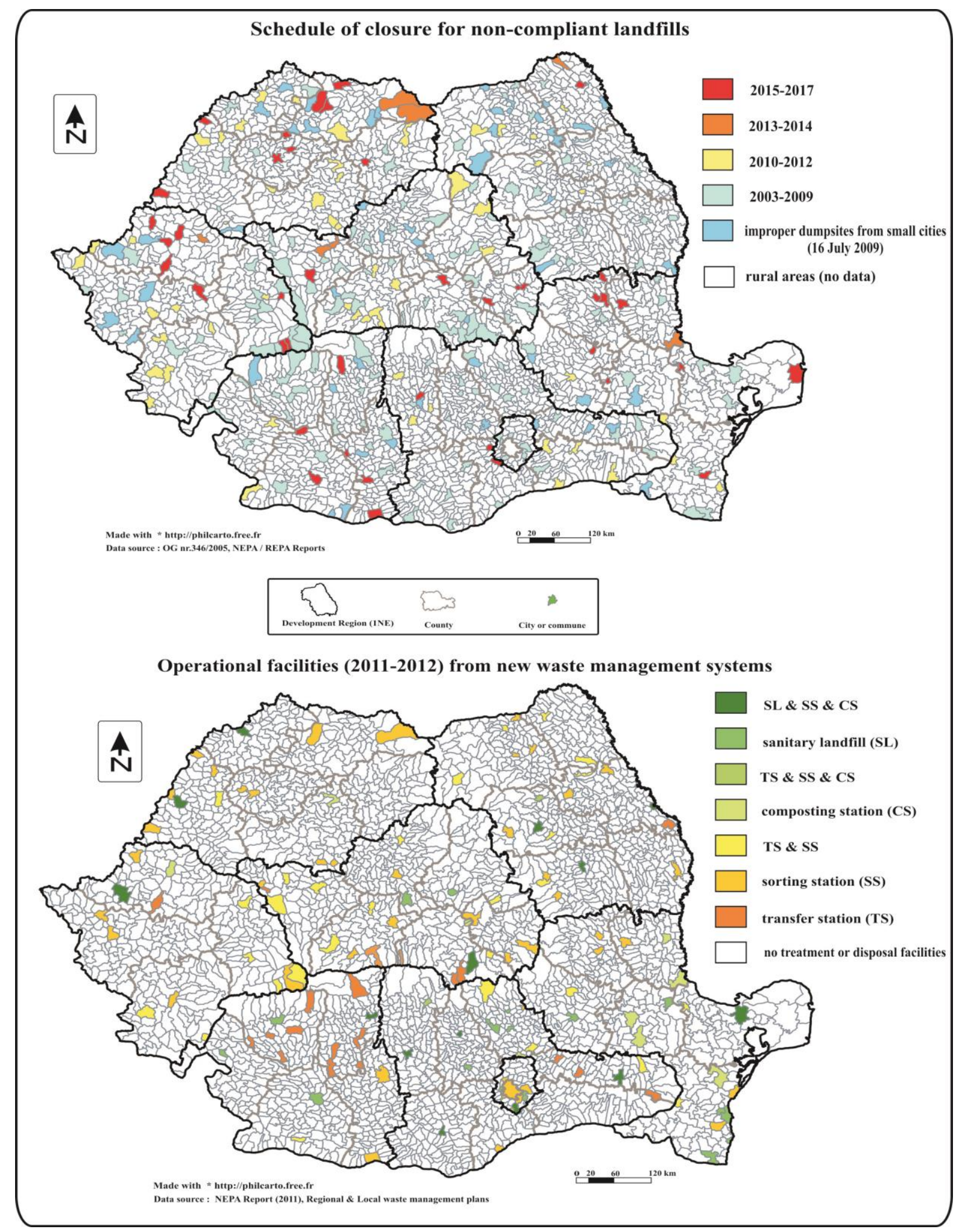

Figure 1: The transition to a modern waste management infrastructure

GIS techniques are used for mapping these old sites in the proximity of urban areas from Norh-East Region. This procedure was achieved using Google Earth images. The black polygons west overlay on digital elevation model (DEM) on regional scale.

The DEM was performed based on digital datasets such as SRTM (Shuttle Radar Topography
Mission). Others vector layers such as hydrographic network and roads (classified by rank in European, national and county roads) were performed based on 1:25000 topographic map of Romania in GaussKruger projection using as GIS soft the TNTMips software 7.0. Built-up areas from ATU (Administrative-territorial units) of towns were 
extracted from Corine Land Cover (CLC-2005). The aim of these maps is to analyze the territorial implications of dumpsites in a geographical context. Buffer area $(2 \mathrm{~km})$ shows the territorial implications of each site to surroundings (Fig. 2).

This analysis is more detailed at local scale (town), using the land use for each site (inside the buffer area of $2 \mathrm{~km}$ ) extracted from CLC at regional scale. In order to examine the distance from landfill site to surroundings and to highlight the improper distances to critical factors (CF) such as, residential area (CF1- continuous urban area), industry \& commercial facilities (CF2), agricultural land (CF3) rivers \& lakes (CF4), forest and protected areas (CF5) buffer areas of $1 \mathrm{~km}$ were also delimited.

These factors are critical because they are sensitive to any environmental pollution threatening the human health and the local biodiversity. Proximity of a non-compliant landfill to these critical factors increases the vulnerability to complex pollution. The location and establishment of sanitary protection area must be determined by EIA studies following the procedure of Order no. 757/2004, otherwise, national regulations stipulates that such sites must not be located in the proximity of residential areas, rivers, protected areas at least at 1 $\mathrm{km}$ distance (Order no.536/1997). Based on buffer analysis at local scale $(0.5 / 1 / 2 \mathrm{~km})$ there was developed an assessment method of landfill location.

Thus, for each critical factor identified on local maps inside the buffer area of $0.5 / 1 /$ or $2 \mathrm{~km}$, a specific number of points correspond as shown in table 1.

Table 1: Assessment of landfill location

\begin{tabular}{|l|l|l|l|l|}
\hline BA(km) & $\mathbf{0 . 5}$ & $\mathbf{1}$ & $\mathbf{2}$ & $\mathbf{> 2}$ \\
\hline CF1 & 0 & 0 & 3 & 5 \\
\hline CF2 & 0 & 1 & 3 & 5 \\
\hline CF3 & 0 & 1 & 3 & 5 \\
\hline CF4 & 0 & 0 & 3 & 5 \\
\hline CF5 & 0 & 0 & 3 & 5 \\
\hline Points & & & & Max.25 \\
\hline
\end{tabular}

The best scenario (max. value of 25) is when all these critical factors are located outside the $2 \mathrm{~km}$ buffer area from landfill site, but this scenario is more ideal. Each site is ranked according to the total sum of points accumulated from assessment table. Location of these old landfills from North-East may be good (20-25 points), proper (15-20), acceptable $(10-15)$, improper $(5-10)$ or bad $(<5)$ for urban environment.

This method may be complementary to current environmental impact assessments studies (EIA) that focus on in-situ analysis or to strategic environmental assessments studies (SEA). This approach is designed for regional scale including more than 10 sites from different counties in various geographical conditions. In the case of more detailed studies at local scale, these factors may be completed with other ones. Also, the assessment table can be modified according to local features of the county.

\section{Discussion}

Non-compliant landfills are scheduled to be closed in the period 2004-2017 (Fig. 1). This schedule is established following the G.Ono $349 / 2005$ which transposed the Landfill Directive (1999/31/EC).

These sites are ordinarily located inside the administrative territorial units (ATU) of towns, increasing the impact on urban environment. Others are located on the range of periurban villages such as Albești (Mangalia town), Glina (serving Bucharest and other small towns from Ilfov County), Gălbinași (Buzău town), Tomesti (Iași town) etc. Most of this old landfills excedeed the initial design capacity, increasing the toxic potential for local environment.

The closure of these sites does not solve the pollution issue. Lack of waterproofing systems will continue to favor the leachate infiltration into phreatic or surface waters in the proximity. On the other hand, this pollution will be diminished across the time, because there will no be others inputs in the landfill site. In this context, post-monitoring process plays an important role to reduce the potential threats. Some industrialized towns have started earlier to replace these old sites with controlled ones.

The first sanitary landfill for municipal waste was operational since 1995 disposing the amounts of waste generated from Ovidiu, Constanța and Năvodari towns (South-East Region). This site is located on the range of Ovidiu town and has eight cells with a design capacity for $1.600000 \mathrm{~m} 3$ (APM Constanța, 2003). Also, Brăila town has a sanitary landfill since 2002. In 2003, several urban landfills (Ploiești, Slănic, Băicoi, Sinaia) from Prahova County were closed being replaced by sanitary sites from following towns Boldești-Scăeni, Băicoi, Vălenii de Munte and Bănești village (near Câmpina town) and also by a transfer station in Bușteni (PJGD Prahova, 2008). In short time, these landfills have reached the storage capacity being closed earlier than the initial schedule.

The solution of some municipalities was the extension of these sites through the building of new cells. The majority of old sites were closed until 2012 in North-East Region and South Region, but several non-compliant landfills were scheduled to be closed after 2012 in other regions. In some counties, more than 3 non-compliant landfills will be operational until 2017 such as Sălaj, Maramureș, Arad, Vrancea, Olt due to lack of concrete 
investments in this sector. Mixed waste collections have reduced the recycling capacity favoring landfilling and land consumption particularly for larger towns. These sites transformed important areas into degraded lands. Most of communes declared towns during the 2004-2006 period had no access to waste collection services, the household and similar waste generated being disposed in improper sites on surroundings.

This bad practice was widespread in these new urban areas, but these sites were closed and rehabilitated until 16 July 2009 using the same procedure as for rural dumpsites.

This environmental issue was not significant in some counties due to larger number of such towns (Suceava or Maramureș counties). In last years, on the one hand the old sites are replaced by sanitary landfills (serving a large town or as regional site at county level) and, on the other hand, by transfer stations equipped with sorting and/or composting facilities as shown in figure 1 .

This new approach should stimulate the recycling programs and minimize the amounts of waste landfilled particularly for biodegradable fraction in accordance to EU targets. Also, sanitary landfills were built through ISPA projects in Piatra - Neamt and Bacău towns (North-East Region), Aninnosa, Titu (Dâmbovița County - South Region) RâmnicuVâlcea (South-West Region), Galați (South-East Region). Several regional landfills as part of county integrated waste management systems are located outside the ATU of towns, in rural areas which serve both urban and rural areas such as Mavrodin (Teleorman county) or Albota commune (Argeș county).

Transfer stations replace the improper sites from small towns through PHARE projects and several old urban landfills. New integrated urban waste management systems provide beside a sanitary landfill, separate collection, sorting and composting stations as in Piatra Neamț, Bacău, Arad or Brașov towns. Every region and county developed regional and local waste management plans which analyzed the waste management sector and establish the major targets regarding the future of waste management systems. Local authorities, particularly county councils, develop projects regarding the implementation of an integrated waste management system at county scale.

These projects are submitted to SOP ENV programme for financial support. North-East Region is on top of Romanian regions regarding the closure of non-compliant landfills and also for investments in new waste management facilities. At regional scale, these facilities are more developed in the western part of the region (Suceava, Neamt and Bacău) than in the eastern half. This fact is due to the ISPA and
Phare projects which are already implemented in these counties. Since 2007, Piatra Neamt town is a model concerning the waste management infrastructure at regional and national scale and also, an integrated waste management system for whole county was approved through SOP ENV. Moreover, Government funds supported the development an integrated urban waste management system in Iași town. These new facilities are necessary to be implemented in urban waste management systems because the old landfills were operational over 30 years in large towns from North-East Region such as county capitals (Iași, Piatra Neamț, Suceava, Bacău) also occupied significant areas ( $>10 \mathrm{ha})$.

Demographic features of the towns are reflected in the design capacity of landfills. Optimal life for a landfill site is minimum 15 years, but the lack of financial resources for building new sites have determined municipalities to extend the operational period of old landfills over even 45 years (Onești, Hârlău, Bicaz, Huși, Gura Humorului). Waste disposal in small towns ( $<20,000$ inhabitants) was done in unsuitable sites which threatened the local environment even these dumpsites covered insignificant areas (often < 1ha) compared to more suitable sites from well-populated towns (Mihai, 2013).

The poor waste management facilities in the 2004-2009 period led to illegal dumping of household waste. Closure of these dumpsites (16 July 2009) and the non-compliant landfills from larger towns require the development of waste collection services (Fig. 3). Separate collection need to be compulsory in towns for recyclables fractions such as paper/cardboard, plastics or biodegradable waste. Other fractions are also collected from the economic sector, such as glass, metal, wood. Furthermore, Piatra Neamt has two special centers in Mărăței and Dărmănești neighborhoods where bulky waste, WEEE and hazardous municipal waste can be collected. In the proximity of sanitary landfill is located a crushing plant for demolition and construction waste.

These new facilities are the basic elements to achieve the transition from a traditional to an integrated waste management systems which focuses on separate collection, recycling, treatment and less landfilling. North-East Region is included in Balkwaste projects financed by LIFE07/ENV/RO/686 as case study for Romania.

The aim of this project is to establish a waste network for sustainable solid waste management planning and promotion of integrated decision tools in the Balkan Region along with Slovenia, Bulgaria and Greece. 


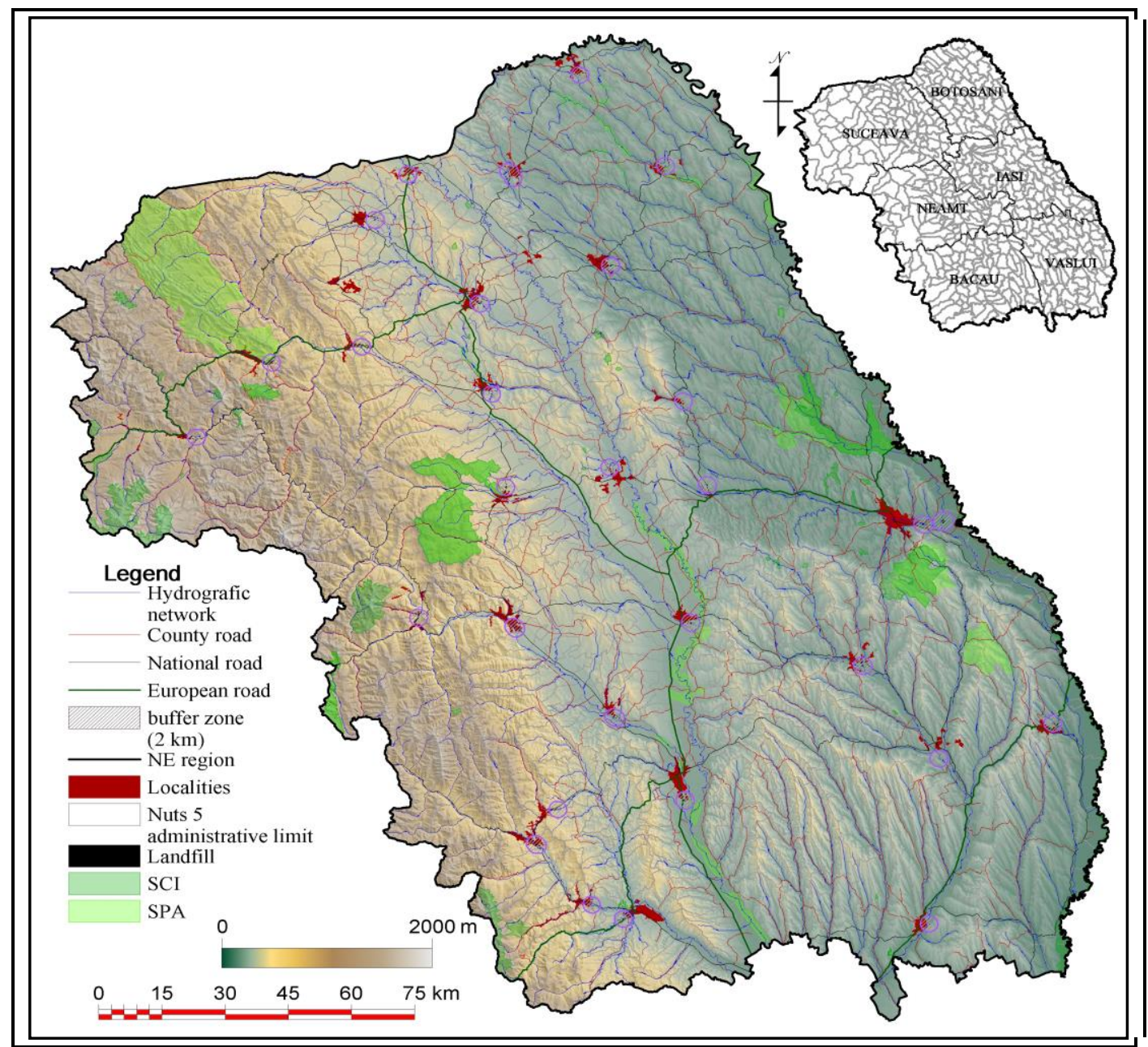

Figure 2: Landfills in the proximity of built-up areas of cities from North-East Region

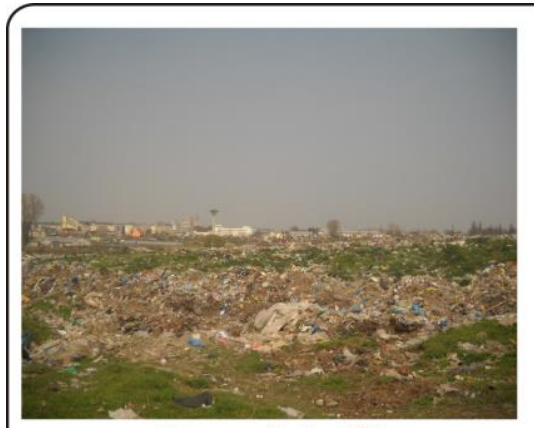

Roman.city landfill, Neamt County.Apr.2011

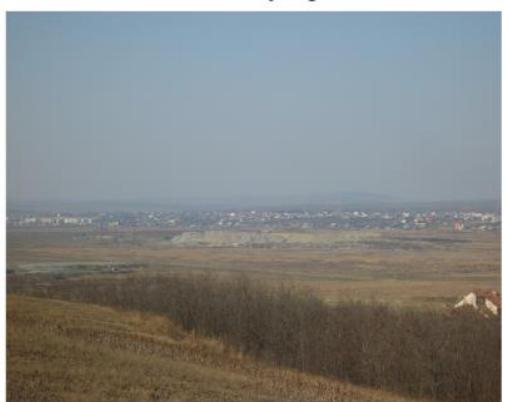

Iași,city landfill (Tomești) Iași County,Apr.2009.2011

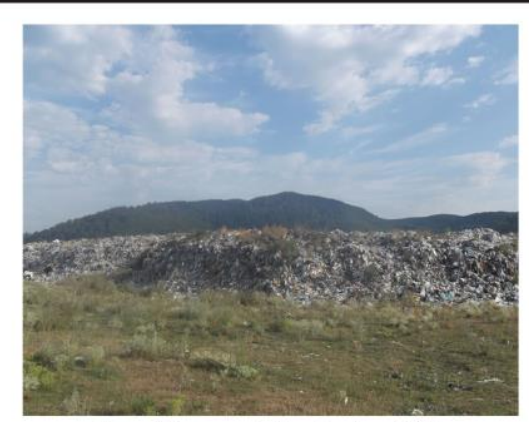

Gura Humorului -city landfil Suceava County,July 2012

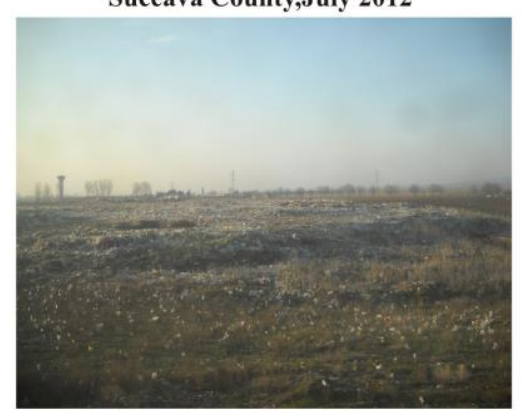

Pașcani,city landfill, March 2010,Iași County

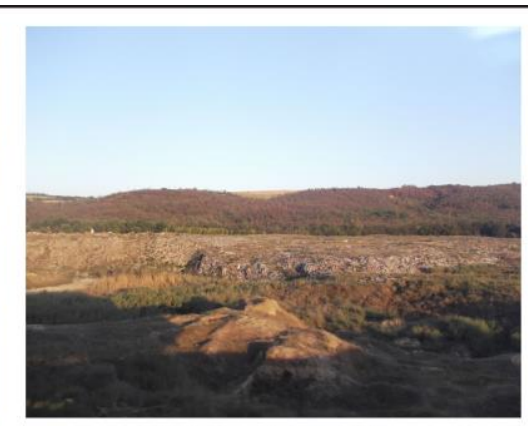

Bârlad - city landfill Vaslui County, Sept. .2012

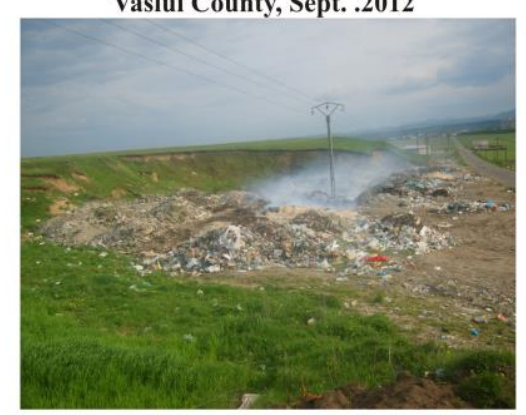

Local dumpsite in a small city Roznov (Slobozia) Neamț County,Apr.2008

Figure 3: Non-compliant landfills from study area 
This paper focuses on regional scale assessment of the location of old non-compliant sites in the proximity or urban areas. Such landfills are a source of complex pollution and this threat was facilitated by an improper location related to critical factors. Applying the assessment table for each landfill site from the study area (32 in total), it resulted that most of dumpsites are located in bad or improper sites ( $<10$ points), too close to the built -up areas of towns and on the other hand too close to the rivers, despite the national regulations that specify a distance at least $1 \mathrm{~km}$ to these critical factors. These old landfills were built during the communist period (1960-1990), disregarding the environmental issue. In this context, their location in the proximity of towns led to various implications on urban environment. Geographical barriers especially in the mountain areas reflect the low scores for landfill sites from following towns: Vatra Dornei, Câmpulung Moldovenesc, Gura Humorului (Suceava county), Bicaz (Neamt county) Comănești, Moinești and Târgu Ocna (Bacău county) (Fig. 4). These towns have no suitable or acceptable options for these facilities. Old landfills will be replaced by new transfer stations equipped with sorting and composting plants. Furthermore, small towns from mountain region as Broșteni, Frasin, Slănic Moldova disposed the municipal waste in open dumps or on river banks, just as rural communities.

The vulnerability of mountain rivers to waste dumping is significant in the proximity of localities (Mihai et al., 2012). Carpathian region should be avoided in territorial planning of new landfills. Beside critical factors which are difficult to avoid in this region, such as residential areas, rivers, forest \& protected areas, the slope, climatic features and geomorphological processes are additional restrictive factors. Different geographical and social economic conditions reflect various land use patterns in the proximity of landfills. In this context, critical factors vary from case to case, particularly for CF2, CF3 and CF5. The urban landfills are often located on terraces or floodplains of major rivers such as the Bistrita (5 sites), Moldova (4 sites), Suceava (1), Trotuș (3), Bârlad (3) and Bahlui (2). Other sites are located in the proximity of their tributaries or streams. In this regard, only 2 landfills are located outside the $2 \mathrm{~km}$ buffer area (Onești, Hârlău) from rivers and others 5 dumpsites respect the minimum distance of $1 \mathrm{~km}$ (Siret, Bacău, Botoșani, Dorohoi, $\mathrm{Tg}$. Frumos). Furthermore, there are 23 noncompliant landfills polluting for several years the major rivers in the proximity. Also, the new sanitary landfills (Piatra Neamț, Iași) are located inside the buffer area of $1 \mathrm{~km}$ from rivers in the proximity.

The new landfill site (two cells) from Piatra Neamt is located next to the old facility due to economic reasons (Mihai et al., 2013b). This facility uses the existing infrastructure (road access, buildings etc) even this location is bad according to the assessment method. Also, all new facilities such as sorting \& composting stations, crushing plant, leachate treatment, new administrative buildings are located in this perimeter to reduce the operational and transportation costs. On the other side, the new landfill complies with the EU regulations, reducing the potential threats to environment and recently the river sector in the proximity was dammed to protect the site in case of floods. Depending on other factors such as local landscape, infrastructure, economic and social features, the new sanitary landfills may be located near the urban areas, but detailed EIA or SEA studies are required. In another case, new sanitary landfill which serve the Iași town is located in Tutora commune.

This site is more proper than the old site from Tomești locality but acceptable according to assessment location. The urban residential area is outside the buffer area $(2 \mathrm{~km})$, but other critical factors are in close proximity (rivers, arable land). Frequently, residential areas of old sites are in the buffer area of $1 \mathrm{~km}$ threatening the human health and only 3 landfills (Rădăuți, Iași-sanitary) are outside the $2 \mathrm{~km}$, another 6 dumpsites respecting the minimum distance of $1 \mathrm{~km}$ : Vatra Dornei, Târgu Neamț, Bacău, Botoșani, Hârlău and Huși.

Industrial \& commercial facilities (CF2) are exposed to landfills pollution particularly in larger towns such as county seats (Suceava, Piatra Neamt, Bacău, Iași, Vaslui) and agriculture land (CF3) is more significant in the Moldavian Plateau in the proximity of dumpsites from middle and small towns (Siret, Dărăbani, Săveni, Tg. Frumos, Negrești, Huși etc) (Fig. 5). Forest and protected areas as CF5 are more exposed in the proximity of mountain towns (Bicaz, Vatra Dornei etc).

A general overview shows that some sites from Târgu Ocna and Bârlad have accumulated no points $(0 !)$, representing the worst scenario. Most of the landfill sites are bad (12!) related to critical factors, 10 are improper, 9 are acceptable and no site is proper ( $>15$ points). Vaslui county has not an acceptable location (0/4) and the towns from Suceava and Neamt counties are the most vulnerable to landfills pollution.

The maxim values (13 points) are attributed to landfills locations from Iași county (Iași town sanitary landfill, Hârlău, Tg. Frumos) and for Rădăuți. By rank classification, using only the undesirable categories (acceptable/ improper / bad), Iași county ranks first $(3 / 2 / 0)$ followed by Bacău $(2 / 2 / 2)$, Botoșani $(1 / 3 / 1)$, Suceava $(2 / 1 / 4)$, Vaslui $(0 / 2 / 2)$ and Neamț $(0 / 1 / 3)$. 


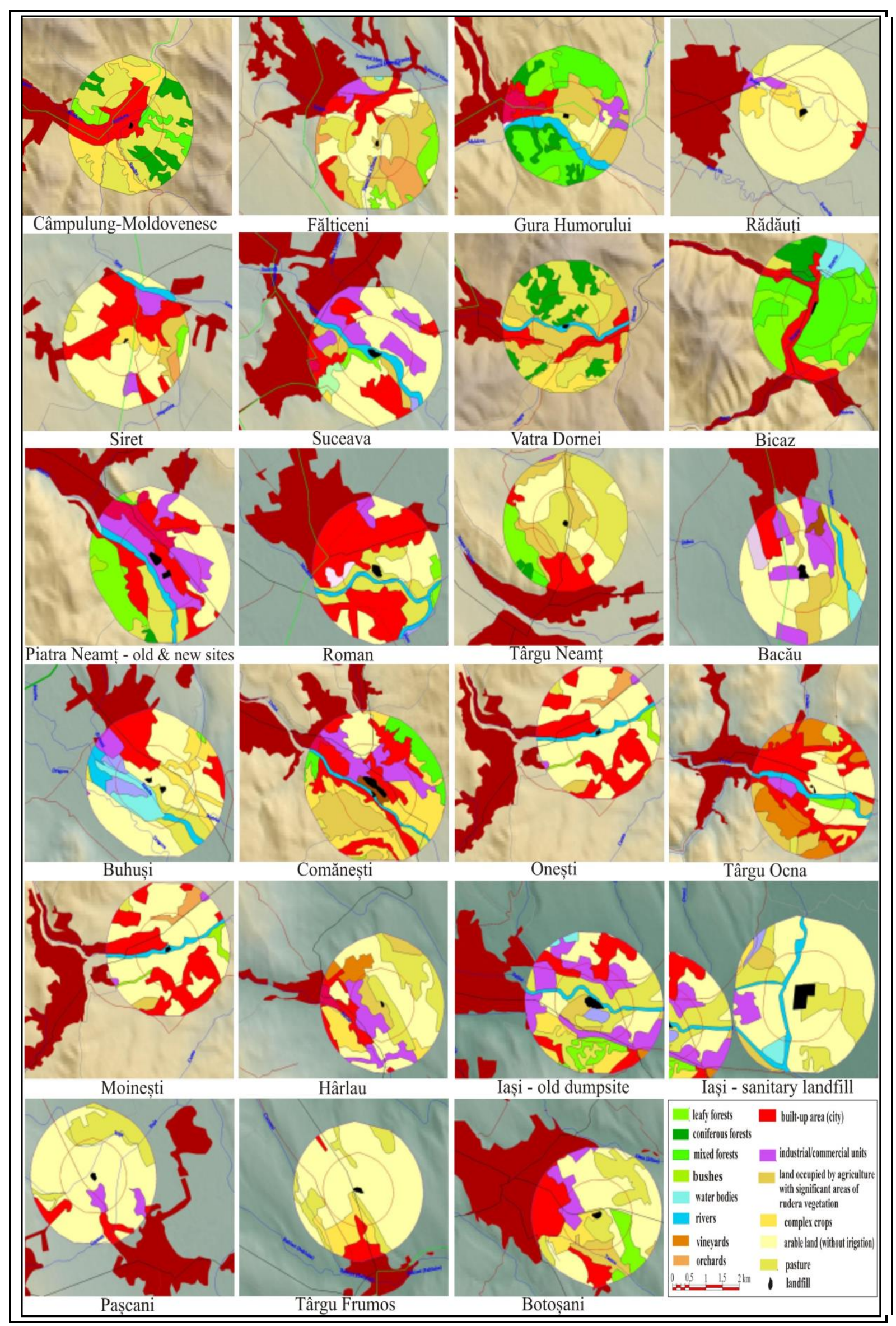

Figure 4: Urban landfills at local scale - buffer areas 
Table 2: Assessment of urban landfills location in the study area

\begin{tabular}{|c|c|c|c|c|c|c|c|}
\hline Landfill & CF1 & CF2 & CF3 & CF4 & CF5 & Total & Rank \\
\hline Vatra Dornei & 3 & 3 & 1 & 0 & 0 & 4 & bad \\
\hline Campulung Mold. & 0 & 1 & 0 & 0 & 0 & 1 & bad \\
\hline Gura Humorului & 0 & 3 & 0 & 0 & 0 & 3 & bad \\
\hline Suceava & 0 & 0 & 0 & 0 & 5 & 5 & bad \\
\hline Siret & 0 & 3 & 0 & 3 & 5 & 11 & acceptable \\
\hline Radauti & 5 & 3 & 0 & 0 & 5 & 13 & acceptable \\
\hline Falticeni & 0 & 3 & 0 & 0 & 5 & 8 & improper \\
\hline Average (SV) & 6.42 & & & & & 45 & \\
\hline Bicaz & 0 & 0 & 3 & 0 & 0 & 3 & bad \\
\hline P.Neamt (old site) & 0 & 0 & 1 & 0 & 3 & 4 & bad \\
\hline P.Neamt - sanitary & 0 & 0 & 1 & 0 & 3 & 4 & bad \\
\hline Roman & 0 & 3 & 0 & 0 & 3 & 6 & improper \\
\hline Tg Neamt & 3 & 5 & 0 & 0 & 3 & 11 & acceptable \\
\hline Total county (NT) & 5.6 & & & & & 28 & \\
\hline Bacau & 3 & 0 & 0 & 3 & 5 & 12 & acceptable \\
\hline Buhusi & 0 & 3 & 0 & 0 & 5 & 8 & improper \\
\hline Moinesti & 0 & 3 & 0 & 0 & 3 & 6 & improper \\
\hline Tg. Ocna & 0 & 0 & 0 & 0 & 0 & 0 & bad \\
\hline Comanesti & 0 & 0 & 0 & 0 & 3 & 3 & bad \\
\hline Onesti & 3 & 3 & 0 & 5 & 0 & 11 & acceptable \\
\hline Average (BC) & 6.6 & & & & & 40 & \\
\hline Botosani & 3 & 1 & 0 & 3 & 0 & 7 & improper \\
\hline Darabani & 0 & 1 & 0 & 0 & 3 & 4 & bad \\
\hline Dorohoi - old (N) & 0 & 3 & 0 & 0 & 5 & 8 & improper \\
\hline Dorohoi - new (S) & 0 & 5 & 0 & 3 & 0 & 8 & improper \\
\hline Saveni & 0 & 5 & 0 & 0 & 5 & 10 & acceptable \\
\hline Average (BT) & 7.4 & & & & & 37 & \\
\hline Iasi - old site & 0 & 1 & 1 & 0 & 5 & 7 & improper \\
\hline Iasi- sanitary & 5 & 3 & 0 & 0 & 5 & 13 & acceptable \\
\hline Pascani & 0 & 0 & 0 & 0 & 5 & 5 & improper \\
\hline Harlau & 3 & 0 & 0 & 5 & 5 & 13 & acceptable \\
\hline Tg.Frumos & 0 & 5 & 0 & 3 & 5 & 13 & acceptable \\
\hline Average (IS) & 10.2 & & & & & 51 & \\
\hline Vaslui & 5 & 0 & 0 & 0 & 0 & 5 & bad \\
\hline Barlad & 0 & 0 & 0 & 0 & 0 & 0 & bad \\
\hline Negresti & 0 & 3 & 0 & 0 & 5 & 8 & improper \\
\hline Husi & 3 & 0 & 0 & 0 & 5 & 8 & improper \\
\hline Average (VS) & 5.25 & & & & & 21 & \\
\hline
\end{tabular}

By average (no. of points / no. of landfills per county) classification, Iași county still ranks first (10.2), followed by Botoșani (7.4), Bacău (6.6), Suceava (6.42), Neamt (5.6) and Vaslui (5.25). Homogenous landscape of eastern counties (Botoșani, Iași and Vaslui) offers more suitable options for landfill sites than the western region (Suceava, Bacău, Neamț).

It is noted that urban areas are facing various challenges for determining a proper location for a new landfill site according to the current legislation. Urban municipalities need to have several options for the location of waste management facilities.

Three critical factors (residential area, rivers \& lakes, forest \& protected ares) must be avoided in the $1 \mathrm{~km}$ buffer area. Furthermore, agricultural land (arable land, crops, vineyards) and industrial and commerce facilities should be avoided at least in 0.5 $\mathrm{km}$ perimeter. New landfills should be more proper located than these old sites due to EU regulations. Decision-makers, local community, NGOs, academic researchers should get involved in this process. Transparency for all waste management projects should also be provided. NIMBY policy is emerging among EU countries concerning the location of landfills or incineration plants (Wolsink, 2010; Davies, 2008).

The location of new sanitary landfills which will serve an entire county should take into consideration the NIMBY scenario. Often, these landfills are planned to be built in rural areas (eg. Girov commune - Neamt County) to avoid wellpopulated urban areas and to have a strategic position at county scale. But they should not be 
placed in the proximity of built-up areas or agricultural land in order to be accepted by the local community. An improper site may have a significant impact on local economy. Urban and rural localities from region will be served in the future by transfer stations and regional landfills.

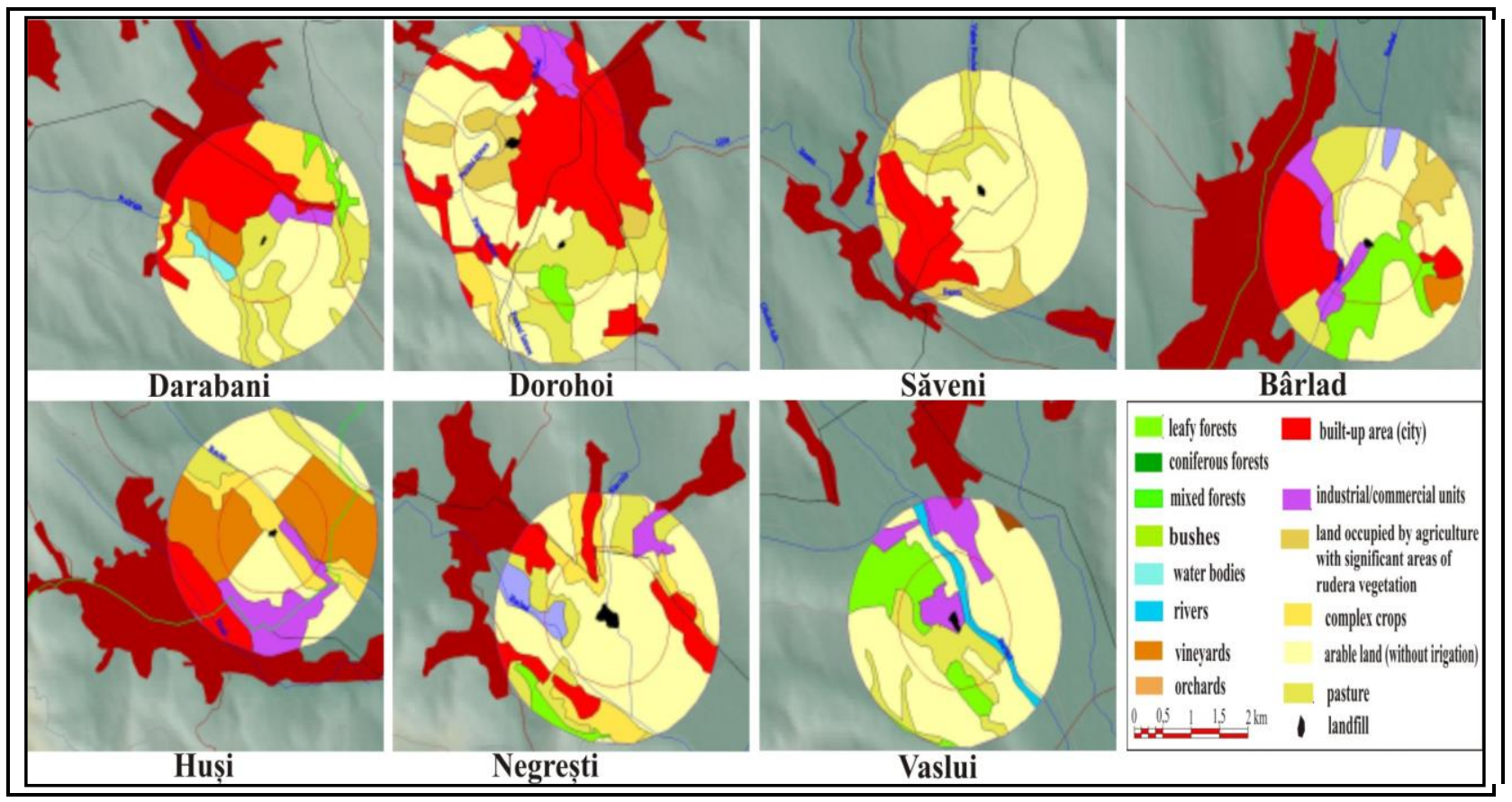

Figure 5: Urban landfills at local scale - buffer areas

These systems will be optimal in the context of full population access to separate waste collection services and high rates of recycling and composting.

\section{Conclusion}

The paper proposed a new assessment method of landfills locations at regional scale taking into account, on the one hand, the proximity of critical factors to such sites based on the buffer analysis through GIS techniques and, on the other hand, the score of landfill sites according to the assessment grid. The results revealed that improper location of old landfills is widespread at regional scale and only Iași county has an acceptable average within the study area. Critical factors are often found inside the buffer area of $1 \mathrm{~km}$ which determined the low scores of landfills (< 10 points). Buffer analysis outlined that rivers, agricultural lands and residential areas are most exposed to pollution, despite the fact that these areas must be avoided in the proximity of these sites. Cities have ignored this environmental issue and the new landfill sites should be more proper located under EU regulations. Romania is facing the transition period from a traditional waste management system where landfilling and mixed waste collection prevails to a sustainable system based on the $3 R$ policy (reduce, reuse and recycle). This goal is still far to be achieved but new waste management facilities are already operational in some urban areas. New integrated urban waste management systems from Piatra Neamt, Bacău and
Iași towns may be guidelines of good practices for North-Est Region and Romania. These noncompliant landfills are the legacy of poor waste management facilities. Separate collection, sorting and composting stations, regional sanitary landfills are key elements for the future integrated solid waste management systems in Romania.

\section{References}

D'Alisa,G., Di Nola,M.F., Giampietro,M.,(2012). A multiscale analysis of urban waste metabolism: density of waste disposed in Campania, Journal of Cleaner Production, 35, 59-70

Davies, A.R., (2008). Civil society activism and waste management in Ireland: The Carranstown antiincineration campaign, Land Use Policy, 161-172

Keser S., Duzgun, S., Aksoy, A., (2012). Application of spatial and non-spatial data analysis in determination of the factors that impact municipal solid waste generation rates in Turkey, Waste Management, 32, 359-371

Lin H.Y., Chen, G.H. (2009). Regional optimization model for locating supplemental recycling depots, Waste management, 29, 1473-1479

Mazzanti, M., Montini, A., Nicolli, F., (2009). The dynamics of landfill diversion: Economic drivers, policy factors and spatial issues.Evidence from Italy using provincial panel data, Resources, Conservation and Recycling,54,53-61

Mihai F.C., (2013). Development of MSW collection services on regional scale: spatial analysis and urban disparities in North-East Region, Romania, $A G D$ Environment and Landscape, 7 (1):13-18 
Mihai F., Apostol L., Ursu A., Ichim P., (2013). Landfills as anthropogenic landforms in urban environment from Neamt county. AES Bioflux 5 (2): 100-108.

Mihai F.C., Apostol, L., Chelaru D.A., Ursu, A., (2013). EU acquis compliance on urban waste management. Case study: Piatra Neamt, Romania, Proccedings of $13^{\text {th }}$ International Multidisciplinary Scientific GeoConference on Ecology, Economics, Education and Legislation, SGEM 2013, 16-22 June, Albena, Bulgaria,vol1: 423430, (DOI:10.5593/SGEM2013/BE5.V1/S20.056)

Mihai, F.C., \& Lămășanu, A. (2013). Spatial analysis of dumpsites volumes from rural territory. Case study: Neamt County, Romania. Forum geografic, XII(1), 5966. doi: $10.5775 / f g .2067-4635.2013 .063$.i.

Mihai F.C., Apostol, L. (2012). Disparities in municipal waste management across EU-27. A geographical approach, Present Environment and Sustainable Development, 6 (1), 169-180

Mihai, F.C., Lămășanu, A., Apostol, L. (2012). Regional disparities in urban population access to sanitation services. Case study: Romania, Mediterranean Journal of Social Sciences, Special issue, 3 (6), 273-279

Mihai F.C, Apostol, L., Ursu, A., Ichim, P., (2012).Vulnerability of mountain rivers to waste dumping from Neamt County, Rom. Geographia Napocensis, 6 (2) ,51-59,

Mihai F.C. (2012)a. Population access to waste collection services: urban vs rural areas in Romania, Bulletin USAMV Agriculture, 69 (2) 464-466, short com.

Mihai, F.C. (2012)b. Geography of waste as a new approach in waste management study, Papers of " Dimitrie Cantemir" Geographical Seminar, 33, 39-46

Mihai F.C., Ghiurcă A.,Lămășanu, A. (2011). Estimation of urban waste generated and uncollected in Romania, Analele Universitătii Oradea, Fascicula: Protecția Mediului, 17(2), 719-724

Moeinaddini M., Khorasani, N., Danehkar A., Darvishsefat A. A., Zienalyan M., (2010). Siting MSW landfill using weighted linear combination and analytical hierarchy process (AHP) methodology in GIS environment (case study: Karaj), Waste Management, 30, 912-920

Pandey P.C., Sharma, L.K., Nathawat, M.S. (2012). Geospatial strategy for sustainable management of municipal solid waste for growing urban environment,
Environ Monit Assess, 184, 2419-2431, DOI 10.1007/s10661-011-2127-2

Passarini F.,Vassura, I., Monti, F., Morselli. L., Villani, B., (2011).Indicators of waste management efficiency related to different territorial conditions, Waste Management, 31,785-792.

Sauri-Riancho, M. R., Vargas , C. D. D., Victoria, E.M., Marrufo , G.M., Lara, C. R., Novelo, M R.I. (2011), Locating hazardous waste treatment facilities and disposal sites in the State of Yucatan, Mexico. Environ Earth Sci 63:351-362 DOI 10.1007/s12665-010-07060

Sener S., Sener E., Nas B., Karaguzel, R., (2010). Combining AHP with GIS for landfill site selection: A case study in the Lake Beysehir Catchment area (Konya, Turkey), Waste Management , 30, 2037-2046

Sumathi V.R., Natesan, U., Sarkar, C. (2008). GIS-based approach for optimized siting of municipal solid waste landfill, Waste Management, 28 ,2146-2160

Wolsink M., (2010). Contested environmental policy infrastructure: Socio-political acceptance of renewable energy, water, and waste facilities, Environmental Impact Assessment Review, 30,302-311

Yashon O., Emmanuel C. K.,Ryutaro T.,(2011). MCDA-GIS integrated approach for optimized landfill site selection for growing urban regions: an application of neighborhood-proximity analysis, Annals of GIS, 17:1, 43-62

*** ANPM,2011, Raport national privind starea mediului

*** APM Constanta, 2003. Raport anual privind starea factorilor de mediu in județul Constanta.

*** ARPM Bacău,2006, Planul regional de gestionare a deșeurilor în regiunea $1 \mathrm{~N}-\mathrm{E}$

*** C] Prahova, 2008, Planul judetean de gestionare a deșeurilor in județul Prahova,

*** Council Directive 99/31/EC of 26 April 1999 on the landfill of waste

*** HG nr.345/2005 privind depozitarea deșeurilor

*** ORDIN nr. 757 din 26 noiembrie 2004 pentru aprobarea Normativului tehnic privind depozitarea deșeurilor

*** ORDIN nr. 536 din 23 iunie 1997 pentru aprobarea Normelor de igienă și a recomandarilor privind mediul de viață al populației (actualizat pâna la data de 30 aprilie 2008*. 